Portland State University

PDXScholar

$1-1-2004$

\title{
Describing a New Environment: Lewis and Clark and Enlightenment Science in the Columbia River Basin
}

William L. Lang

Portland State University, langw@pdx.edu

Follow this and additional works at: https://pdxscholar.library.pdx.edu/hist_fac

Part of the United States History Commons

Let us know how access to this document benefits you.

Citation Details

Lang, W. L. (2004). Describing a new environment: Lewis and Clark and enlightenment science in the Columbia River Basin. Oregon Historical Quarterly, 105(3), 360-389.

This Article is brought to you for free and open access. It has been accepted for inclusion in History Faculty Publications and Presentations by an authorized administrator of PDXScholar. Please contact us if we can make this document more accessible: pdxscholar@pdx.edu. 
Kristen Peterson, photographer (detail), courtesy Missouri Historical Society

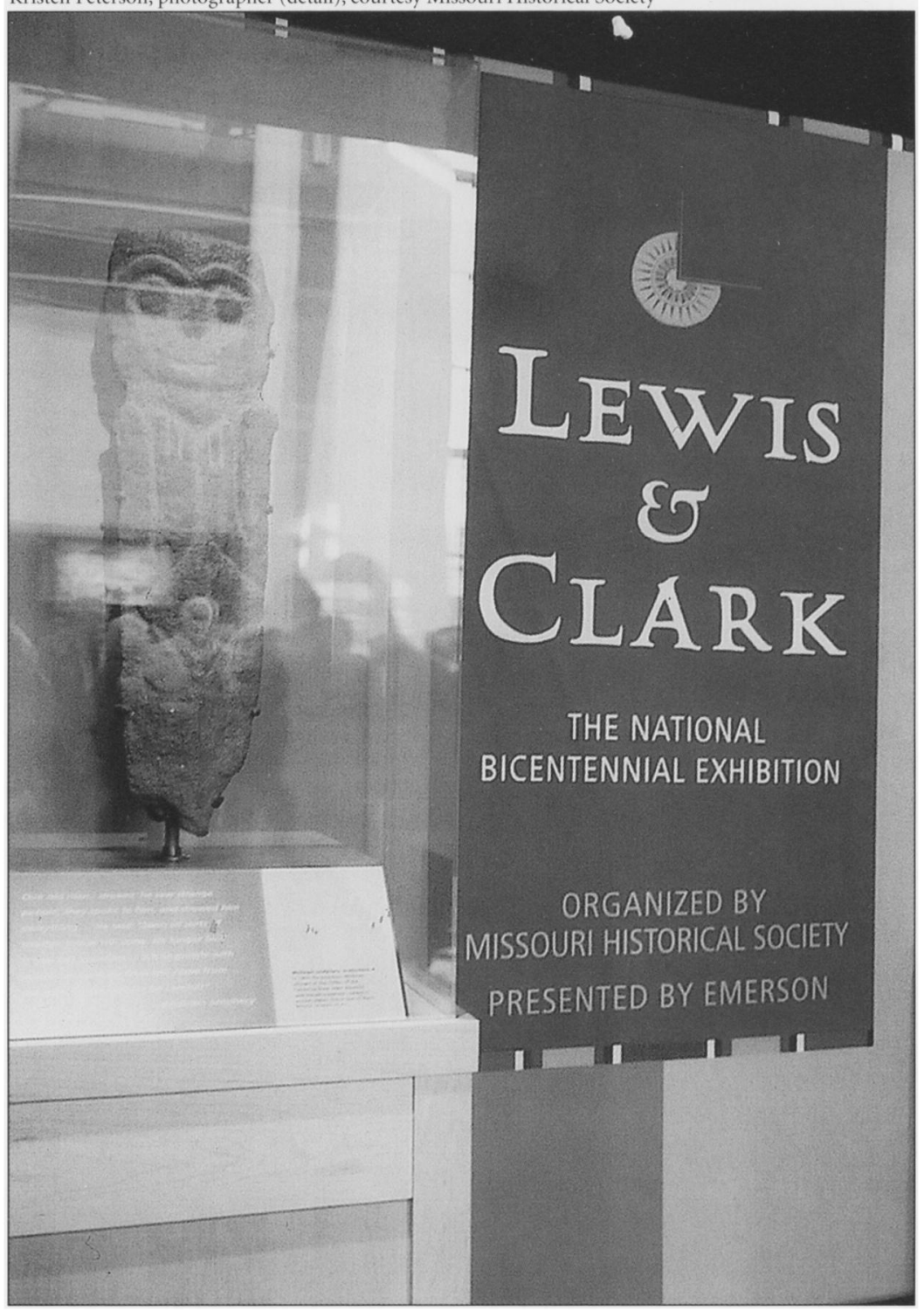

The Lewis and Clark National Bicentennial Exhibition is currently at the Missouri Historical Society in St. Louis. The Oregon Historical Society will host the exhibit from November 2005 through March 2006 - its only venue on the West Coast. 


\section{William L. Lang}

\section{Describing a New Environment}

\section{Lewis and Clark and Enlightenment Science in the Columbia River Basin}

N AUgust 1805, the Corps of Discovery topped the Continental Divide after a laborious journey up the Missouri River - more than thirty-one hundred miles, by William Clark's later reckoning, from their departure point at the river's mouth. ${ }^{1}$ Tracing the Missouri to its sources marked the achievement of a major objective, but the view Meriwether Lewis took in as he looked west from Lemhi Pass startled him. "After refreshing ourselves," Lewis wrote on August 12, "we proceeded on to the top of the dividing ridge from which I discovered immence ranges of high mountains still to the West of us with their tops partially covered with snow." That view dashed the imagined geography Lewis and Clark had carried with them since leaving Fort Mandan in April. They had expected the west side of the divide to mimic the east side and to offer an unencumbered descent to the Columbia River and the Pacific Ocean. Looking into the sawtoothed Bitterroot Mountains put Lewis in a position he had endured before when the geography had surprised him and forced new decisions. As they had throughout the expedition, the co-leaders pondered their options, knowing that their destination might be more distant but also knowing that reaching it was compelling and essential to the success of their mission. ${ }^{2}$

The scene is familiar to students of the great exploration led by Meriwether Lewis and William Clark into the American West. It is a moment of adventure and challenge, the essence of the Lewis and Clark story, a saga of exploration that rivals John Wesley Powell's float of the Grand Canyon, John Glenn's orbit of the Earth, and Neil Armstrong's walk on the moon. 


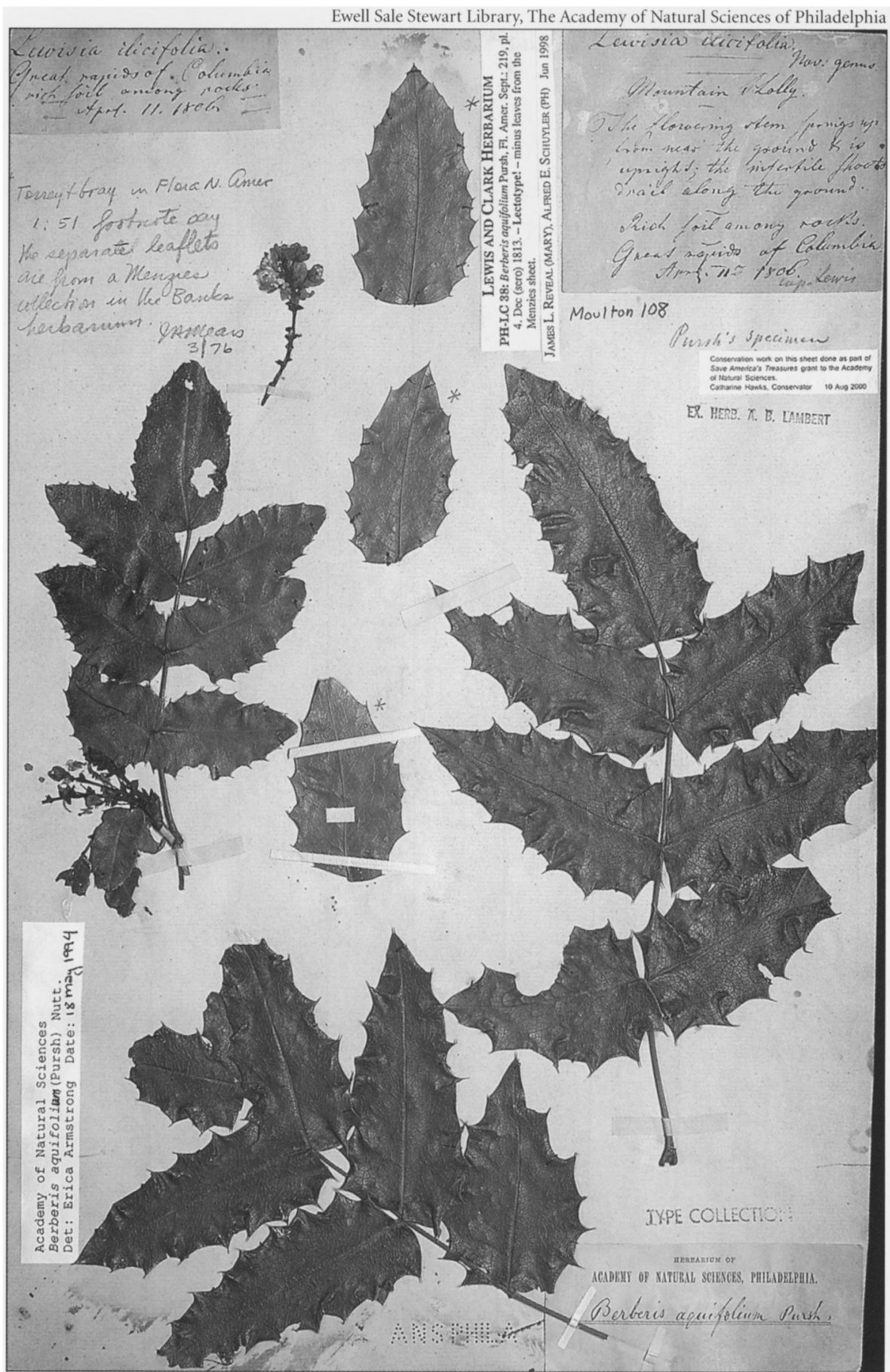

These specimens of Mahonia aquifolium - also known as Berberis aquifolium, or shiny Oregon grape - which Lewis collected at the Great Falls of the Columbia, are part of the Lewis and Clark Herbarium. 
Most Americans have been told the Lewis and Clark story as an adventure, and it has been that way from the first telling of their experiences by Nicholas Biddle in History of the Expedition under Captains Lewis and Clark in 1814 to Stephen Ambrose's enormously successful Undaunted Courage in 1996. The expedition has been a story of accomplishment, often set within a patriotic context. Its background, proximate causes, and stated objectives, however, are not well known to the general public. Even less known and understood are the exploration's scientific purposes. Although President Thomas Jefferson created the expedition for nationalistic, geopolitical, and economic reasons, he also had science in mind when he sent Lewis and Clark to the West two centuries ago. ${ }^{3}$

Science in the eighteenth century had developed principally as an investigation of natural phenomena and the diversity of life. Enlightenment scientists, historian Donald Worster has argued, pursued the description of nature while they also investigated the apparent harmony resident in the natural world. Lewis and Clark carried these Enlightenment scientific interests and assumptions with them as they explored the Columbia River Basin, and their journals disclose their comprehension of the environment as natural and human ecology. They saw the lands west of the divide, in part, as scientists, and as scientists they documented the relationships between people and environment for the scientific enterprise. ${ }^{4}$

A case can be made that Jefferson's interest in the American West grew out of his fascination with the natural world and his pursuit of scientific information about regions west of the Appalachian Mountains. He had science on his mind in 1783, just after Britain and the United States signed the peace treaty, when he first articulated the idea for a western exploration and tried to enlist George Rogers Clark as expedition leader. Clark was one of the young nation's most experienced soldiers, a veteran of Revolutionary War campaigns on the western frontier, an exponent of western expansion, and someone interested in scientific discovery. Writing to Clark in December 1783, Jefferson thanked him for a packet of "shells and seeds" and hoped he would find and send along "different species of bones, teeth and tusks of the Mammoth." Having directed Clark's attention to scientific collecting, Jefferson played on Clark's patriotism by disclosing his anxiety about British explorers getting a jump on Americans in surveying the western territories. Would Clark take the lead, Jefferson asked, in stealing a march on the British and take on an American expedition for scientific and political reasons? Clark replied that he would send along some bones he had collected; but though he thought a western expedition 
was "what I think we ought to do," he could not afford to leave his affairs for two years of exploring. ${ }^{5}$

The idea of western exploration stayed alive in Jefferson's mind. Three years after his entreaty to Clark, he tried to support John Ledyard, an American adventurer who had planned to travel from west to east across North America. That effort failed when Russian officials detained Ledyard in Siberia on his way to the Pacific. In 1793, Jefferson again pursued his idea of exploring the West when he made arrangements with French naturalist Andre Michaux to survey the Missouri River country, but Michaux's political activities in America on behalf of the French revolutionary government made him a liability and thereby killed the plan. ${ }^{6}$

Jefferson's schemes for a western expedition varied, but his focus on scientific discovery punctuated each effort. The scientific questions he included in his letter of instructions to Meriwether Lewis on the eve of the expedition in 1803 , for example, came directly from earlier directives he had sent to Michaux. Both lists of instructions rested on the president's interest in science and his desire to expand scientific knowledge through discovery. The most daunting tasks in the lists were natural history questions, queries that Jefferson posed in his own research and his wide reading in scientific literature. The best documentation of Jefferson's attention to natural history is Notes on the State of Virginia (1787), his only book. In it, Jefferson disclosed a measured and disciplined mind with an expansive curiosity and a method that served as a kind of template for subsequent American natural history investigations. The book was a compilation of his answers to queries about conditions in America that a French diplomat stationed in Philadelphia had posed in 1780. Notes on the State of Virginia ranged broadly and belied its title by taking in subjects beyond the confines of Virginia's political boundaries. It was singular in its effect, as most historians of science agree, because of its attention to comprehensive description and categorizing of nature. Jefferson sought no less than an environmental portrait of America. ${ }^{7}$

Jefferson expected Lewis and Clark to follow his method. He set a high standard, operating in a demanding world of Enlightenment science that included geology, botany, mineralogy, ornithology, chemistry, astronomy, and other scientific disciplines. His interests, though, hewed tightly to observation and empirical discovery, and he eschewed analysis. He tended toward the practical, especially knowledge that furthered agriculture, his dominant life-long interest. His comment to a friend in 1809 after leaving public office is revealing: "Nature intended me for the tranquil pursuits of 
science." ${ }^{\prime}$ As historian Charles Miller explains, "public service made up the interludes" in Jefferson's life. He centered his existence at Monticello, where agricultural experimentation, the mastery of land management, and the pursuit of scientific knowledge were his constants. Jefferson pursued his interests with like-minded men through organizations such as the American Philosophical Society in Philadelphia, which included in its membership those most accomplished in American science — John Bartram, Benjamin Franklin, Benjamin Smith Barton, David Rittenhouse, and Benjmain Rush — and politics - Alexander Hamilton, Thomas Paine, and John Marshall. They freely mixed discussions and correspondence about scientific discovery and political philosophy among a broad range of subjects. ${ }^{9}$

Jefferson and his circle of scientific empiricists read the works of European scientists such as Carl Linnaeus, George Le Clerc compte de Buffon, and George Cuvier. They compared findings among European scientists with natural histories produced by eighteenth-century Americans. In general, Jefferson and his scientific correspondents accepted a static view of the natural world as an eternal creation where all plants and animals that have ever been on earth remained alive. Mammoths, Jefferson wrote in Notes on the State of Virginia, likely still existed out west in "their aboriginal state, unexplored and undisturbed by us, or by others for us. He may as well exist there now, as he did formerly where we find his bones." ${ }^{\prime 10}$ Those beliefs were consistent with the Great Chain of Being, which categorized living creation into hierarchical orders of greater and lesser beings. Jefferson and other Enlightenment naturalists focused on the idea that order prevailed on earth in the living kingdoms of plants and animals. Linnaeus's outline taxonomy of that world - the binomial naming of plants and animals - reified the idea of order and became the scientific basis for surveying the natural world.

Although Linnaean ideas remained dominant in Jefferson's day, increasing discoveries of plants and animals in different lands across the globe stimulated new ideas about nature. Natural historians Johann Reinhold Forster and Alexander von Humboldt broke new ground by studying relationships among plants and animals in specific bioregions and suggested that nature might not be static, that fundamental change might be inherent in natural processes. Buffon hinted that nature might be more dynamic than the Great Chain of Being theory supposed, but he stopped well short of any idea that considered the evolution of species. Buffon's approach to the classification and description of nature veered from Linnaeus's by emphasizing relationships among plants, animals, and geography in real 


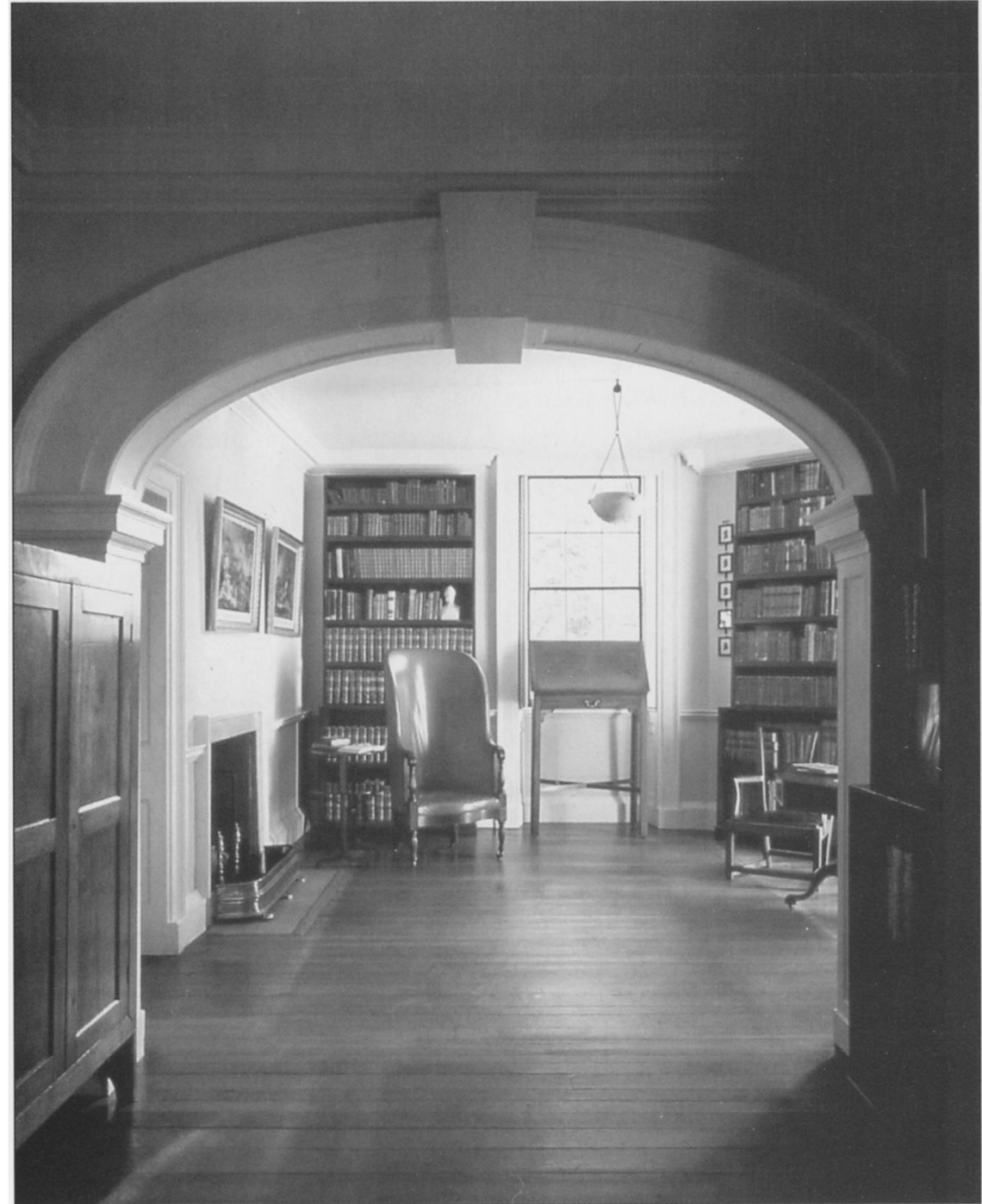

In his library at Monticello, Thomas Jefferson poured over his collection of books, maps, and specimens about the North American West.

settings. Jefferson's antagonism toward Buffon's dismissal of American nature as inferior to Europe's left him a stronger adherent of the more abstract Linnaean approach to classifying nature. He took a conservative line, believing in the perfection of nature and an orderly creation. ${ }^{11}$

Jefferson sent Lewis and Clark west as Linnaean discoverers. They were to report on an environment that no scientist had seen and to bring back a catalog of western America. Their discovery, however, had a narrow defini- 
tion. As Albert Furtwangler tells us, "They could encounter nothing that was wholly unpredictable or beyond ready comparison to things already well known, nothing that could challenge accepted patterns of thought."'12 Lewis and Clark documented their travel as Jefferson had specified, and they did it as natural historians and as representatives of their nation. They made a catalog of nature by measuring and describing the environment. Their notations are purposeful, direct, and unadorned by aesthetics or curiosities, two rhetorical devices that would become staples of travel writing during the nineteenth century. They approached their task with a competitive determination to record the natural world for the benefit of the nation; but as historian Thomas Slaughter has suggested, they did not hesitate to manipulate their journal entries to enhance their discoveries. In short, Lewis and Clark were not unaware of their place in history and of the singular import of their documentation of the new lands, especially those west of the Continental Divide. ${ }^{13}$

How the explorers approached their scientific task is as important as what they recorded. Modern scientific enterprise, dominated as it is by specialization, obscures the integrated character of natural history inquiries in the early nineteenth century. For Jefferson, discoveries about the American landscape were broadly environmental and inclusive. They had utility if the descriptions explained how animals and plants inhabited the land and, especially, where they fit in the Great Chain of Being hierarchy. How human beings fared in the newly described environments had even greater significance. In Notes on the State of Virginia, Jefferson specifically connected aboriginal people to their environments and took special note of their considerable strengths of character, their similarity to Europeans, and their distinct lack of civilization. In part, Jefferson wanted to counter Buffon's disparagement of American nature by providing evidence that American Indians exhibited the full range of human physicality, emotion, and culture. He compiled charts of comparative information about North American Indians and recounted events that demonstrated their prowess and intelligence. Jefferson challenged Buffon

to form a just estimate of their genius and mental powers. More facts are wanting, and great allowance to be made for those circumstances of their situation which call for a display of particular talents only. This done, we shall probably find that they are formed in mind as well as in body, on the same module with the Homo sapiens Europeans.

Jefferson's approach to the exploration of the American West joined investigations of Indian people, their cultures, and the environment that 
sustained them. The extensive list of queries about Indians that he included in his instructions to Lewis and Clark follow directly from this ambition. He sent them west purposefully to investigate the relationships between Indians and the environments they encountered, to describe the world in Linnaean terms, to record the character of the people they met, and to compile Indian lexicons that might document their antiquity and perhaps how they came to America. ${ }^{14}$

Lewis and Clark strived mightily to answer Jefferson's questions about Indians west of the divide. In some ways they succeeded, but there is little doubt that they often misunderstood what they saw or failed to grasp its significance. As historian James Ronda has brilliantly explained, Lewis and Clark gathered far more ethnographic information during their stay at Fort Mandan on the Missouri in 1804-1805 than they did at Fort Clatsop at the mouth of the Columbia River in 1805-1806. At Fort Clatsop, they encountered a much different political situation, and the Corps had less amicable relations with local Indians. It is also true that Lewis and Clark became more and more disenchanted with the Indians they met on their descent of the Columbia to the coast. In the Columbia River Basin, the explorers encountered Indian groups that were significantly different from those they had met along the Missouri. Most were unknown to EuroAmericans, unlike the Missouri tribes, who had done business with British and Spanish traders for decades before Lewis and Clark went upriver. ${ }^{15}$

The Columbia River Basin also represented a different environment from the one they had traversed on the east side of the Continental Divide. For this reason and others, it was in the Columbia drainage that Lewis and Clark collected a significant majority of their botanical specimens and observed most of the animal and plant species they introduced into the scientific catalog. They followed the lead of natural scientists by carrying reference books to aid in classifying and describing what they saw. In their baggage were two volumes of Linnaeus's taxonomies and Benjamin Smith Barton's Elements of Botany. Although they rarely used Latin names for the unfamiliar plants they encountered, the explorers often referred to families and, in some descriptions, to phyla. With a little imagination, we can see Lewis with text in hand, puzzling out the classification of a plant he had just discovered and collected for his herbarium as he applied a common name to describe it. Elijah Criswell noted some decades ago that Lewis and Clark appropriated names they freely borrowed from Indian informants, adapted from nomenclature for like species, or wholly invented to describe new finds. Lewis and Clark did not avoid Jefferson's 
instruction to create a catalog - they made list upon list and included tables of measurements in their journals - but their practical approach to scientific description verged more toward a holistic viewpoint that mixed specific notations on plant and animal species with comments on patterns of living among Indians. ${ }^{16}$

The explorers' narrative was a broad-gauged, almost panoramic report of the environment they encountered, which took in village living conditions, sources of food, economic conditions, and natural resources. What we read in the journals are descriptions of relationships between Indian people and the environments they inhabited that are evident, even palpable. The explorers' method was situational. They identified and collected plants opportunistically, especially when they stayed for many days or weeks at one camp and local conditions allowed them to bulk up their collections. Time sequences in their journal entries are often blurry, so it is not clear which conclusions they drew on the spot and which they constructed later when they wrote up their daily notations and had time to make comparisons and consult descriptions in Linnaeus and Smith. Regardless, it is clear that in the process of discovering new species the explorers also broadened their understanding of the environment; and they often learned about Indians' use of plants, their subsistence strategies, and the resources they considered important. There are many examples in the journals that illustrate these connections between people and environment, but the explorers' residence at three important places in the Columbia River Basin - the Great Falls of the Columbia, Fort Clatsop at the Pacific Ocean, and Camp Chopunnish on the Clearwater River in present-day Idaho - will serve to illustrate the point.

\section{The Great Falls of the Columbia}

During the late fall of 1805 , in their descent of the Columbia, Lewis and Clark canoed through a constricted and dangerous section of rapids and falls, one of the most remarkable environments in western America. They had descended the lower Snake River through a sere landscape bereft of trees and on a river course complicated by more than a hundred rapids. Three days after leaving a band of Walula Indians near the mouth of the Snake, the exploration flotilla reached a group of islands and falls that stretched across the Columbia from bank to bank. At the Great Falls of the Columbia the river dropped more than forty feet over basalt ledges that blocked navigation and forced salmon to leap the barrier to reach 
their upriver spawning grounds. One of the great fishing locations for aboriginal people in North America, the falls created a source of wealth that Indians had used for ten millennia before Lewis and Clark came in late October 1805. Although they arrived after the major summer fish runs, when thousands gathered at the falls to fish, trade, and socialize, they could not mistake its importance.

In a distance the explorers estimated to be sixty-five river miles, they saw 140 lodges, many large enough to house several families. Indian wealth was visible, as Clark recorded on October 22, in "great numbers of baskets of Pounded fish on the rocks Islands \& near their Lodges[.] thos are neetly pounded \& put in verry new baskets of about 90 or 100 pounds wight." Lewis and Clark had paddled into the pivot point of the Columbia River, the place where tribesmen from the interior met and traded with downriver people, who brought manufactured goods acquired by trading with Euro-American mariners. ${ }^{17}$

There could be no mistaking the economic importance of Celilo Falls, the Long Narrows, and the Cascade Rapids. Fishing stations dotted both sides of the river, although most settlements were on the north bank. Lewis and Clark focused as much on protecting their own trade goods from Indians, whom they perceived as thieves, as on navigating the rapids and whirlpools. They failed to establish trade relations and perfect some kind of political agreement with Indians at the Great Falls, but they fully comprehended the importance of the geography. Clark carefully sketched the riverine landscape, the locations of major tributaries to the Columbia, and the locations of the villages. His manuscript maps include notations on river obstructions, rapids, and currents, especially where eddies and whirlpools posed problems for navigation and created prime fishing spots. They also include measurements of stream widths, tracings of tributary courses - which came from Indian informants - and the locations of nearby highlands and mountains. Per their instructions, Lewis and Clark documented cartographically the shape of the Great River of the West and its strategic landscape..$^{18}$

Although they were inconsistent in their appraisal of the resident Indians, Lewis and Clark tended to describe them as "pore," noting in their journals that they "have but little wood which they bring up the river."19 At the Cascades, downriver from Celilo and the Long Narrows, Clark described villagers as "tirty in the extream, both in their person and cooking ... They asc high prices for what they Sell and Say that the white people below give great prices for every thing \&c." ${ }^{20}$ Yet, when Clark described 
their fishing industry, he emphasized the Indians' skill and ingenuity in preserving salmon for use and trade. "Thus preserved," Clark wrote, "those fish may be kept Sound and Sweet Several years, as those people inform me, Great quantities as they inform us are Sold to the whites people who visit the mouth of this river as well as to the nativs below." ${ }^{21}$

Poor these Indians might have been in Clark's estimation, but they evidently had control of a significant resource - hundreds of sacks of pounded salmon, by the explorers' count - and they had managed to stretch their influence to the coast, several days' travel to the west. The explorers also recognized the Indians' skill in constructing their houses, which Clark described in detail near the Long Narrows. The houses required large timbers that produced useful bark and wood that could be split, among the principal attributes of western red cedar (Thuja plicata), which Lewis had first described for science on the Lolo Trail in September. Clark commented on the Indians' use of cedar planks, bark, and shingles, but he also knew that cedar did not grow along the middle Columbia. "The face of the Countrey, on both Side of the river above and about the falls," Clark wrote on October 25, 1805, "is Steep ruged and rockey open and contain but a Small proportion of erbage, no timber a fiew bushes excepted." Inquiring about the source of cedar timbers, he found that "the natives at the upper falls [Celilo Falls] raft their timber down Towarnehooks River [Deschutes River] \& at the narrows take theirs up the river to the lower part of the narrows from this Creek, and Carry it over land 3 miles to their houses \&c." ${ }^{22}$

Although it was not as clear on their downstream trip as when they returned upriver the following year, the explorers began to understand that Indians along the Columbia drew from their environment much as the river drew from its tributaries in the surrounding hills - that the riverine landscape did not explain how Indians lived, what environmental resources they relied on, or what effort it took to acquire them. The explorers spent about the same length of time in the Columbia Gorge during their descent of the river in 1805 as they did in their ascent in 1806, but they passed in different seasons - October on the descent, April on the ascent. Their botanizing in 1806 resulted in many more discoveries and a greater understanding of how Indians used the plants they harvested and gathered.

In 1805, Lewis and Clark collected several important plant species near the falls: vine maple (Acer circinatum), madrone (Arbutus menziesii), dull Oregon grape (Mahonia nervosa), and California hazelnut (Corlyus california). Indians used vine maple in manufacturing hoops for fish nets 


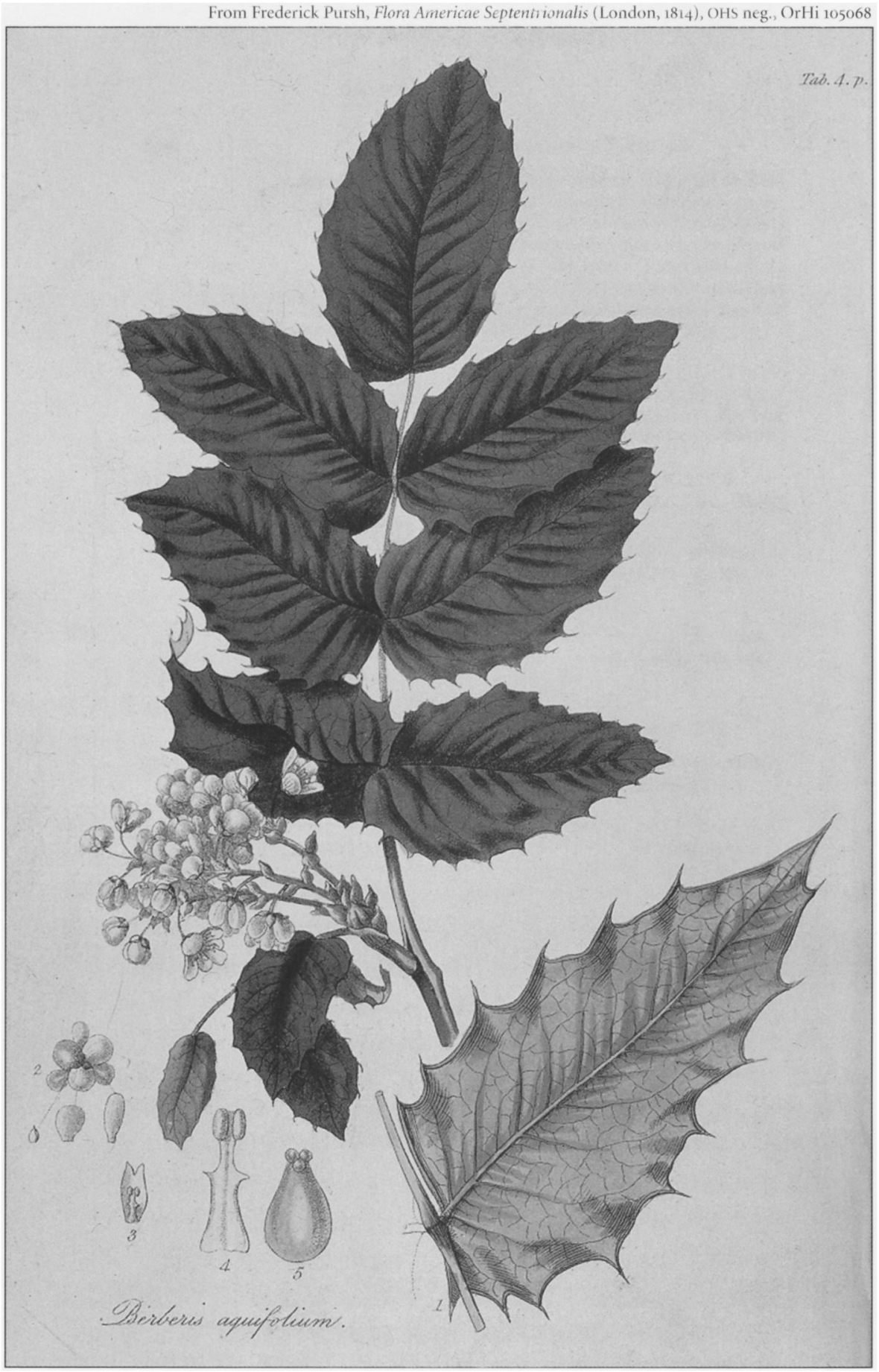

The label on the herbarium specimen of this plant read: "Leiwisia nervosa. New genus.

Mountain Holly from the great Rapids of the Columbia. October 1805." Modern classification identifies it as Mahonia nervosa (formerly Berberis nervosa), dull Oregon grape. 

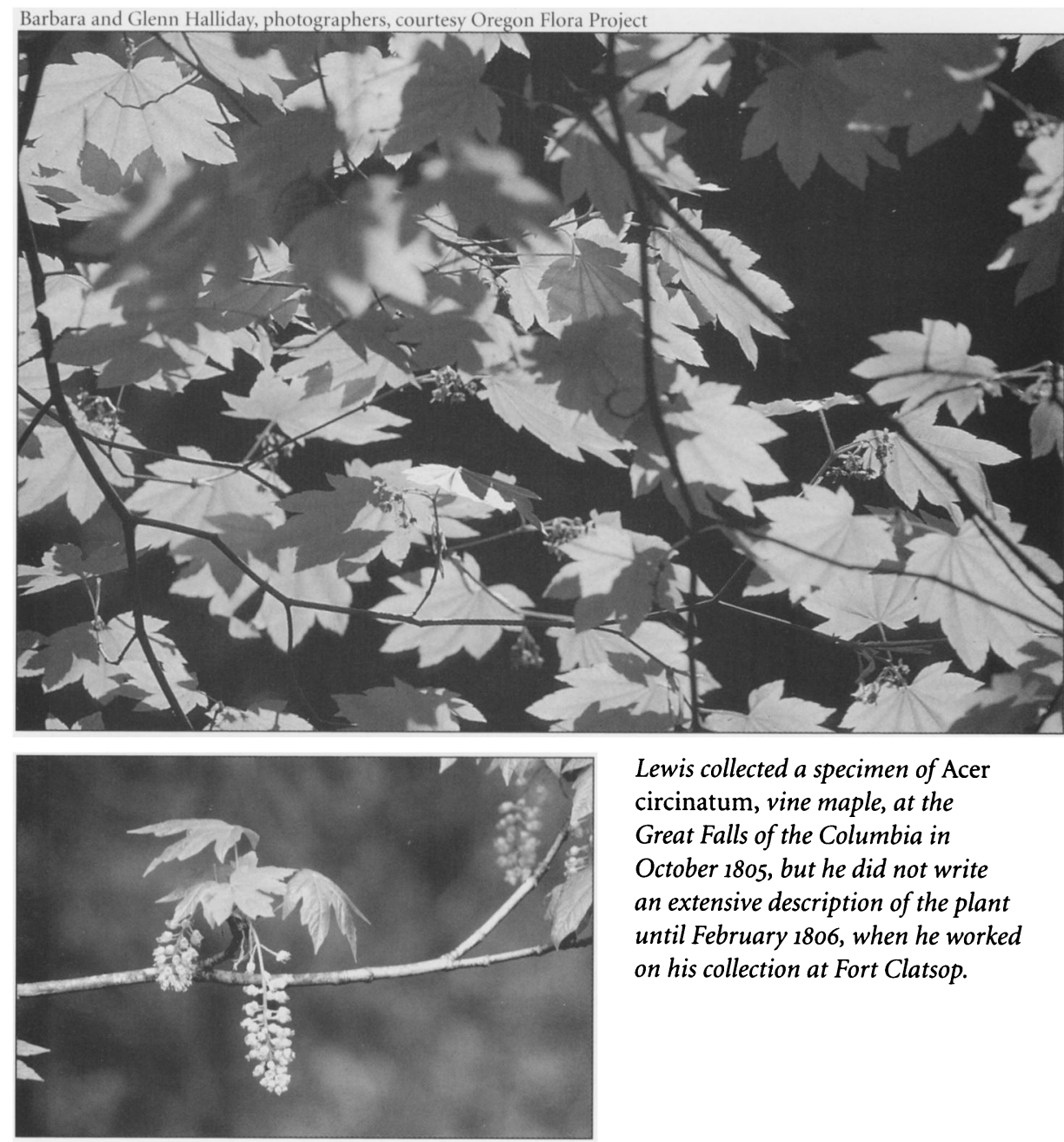

Lewis collected a specimen of Acer circinatum, vine maple, at the Great Falls of the Columbia in October 1805, but he did not write an extensive description of the plant until February 1806, when he worked on his collection at Fort Clatsop.

because of its light weight and strength, and they used its sinewy limbs to build weirs and sweatlodge frames. Lewis identified the specimen he collected as "A very handsome species of maple. On the great rapids of the Columbia." ${ }^{23}$ Lewis collected dull Oregon grape at the Long Narrows and described it later, during the long stay at Fort Clatsop. The plant he described as one of "two species of ever green shrubs" - the other was shiny Oregon grape (Mahonia aquifolium) - fascinated him because of its extraordinary leaves and stems. Indians used the berries of both plants, which are sour to the taste, almost bitter, as aids to digestion and for other medicinal uses. ${ }^{24}$ Near the mouth of the Deschutes River, Indians offered Lewis and Clark food from the Oregon white oak (Quercus garryana): 
"Acorns of the white oake, those Acorns they make use of as food and inform us they procure them of the natives who live near the falls below [Celilo Falls]." 25 The following day, they learned that Indians also harvested hazelnuts from trees in the Deschutes River drainage, and a week later at the mouth of the Klickitat River on the north bank they again had hazelnuts dropped in their hands from Indians who ranged up that tributary stream to gather the nuts, which they ate roasted and raw. The explorers documented this wide use of the environment without commenting on the web of relationships between people and environment, though they encountered it day by day on the Columbia. ${ }^{26}$

On their way back upriver in 1806, Lewis and Clark had a difficult time negotiating with Indians at the falls. They had hoped to purchase sufficient horses to go overland to the Nez Perce camps on the Clearwater River in present-day Idaho. "They have vexed me," Lewis wrote of the Indians at the falls. He thought them unduly stingy and too quick to pilfer goods, but it is clear that the Indians had little incentive to trade with the Corps, who had few goods to trade and addressed the Indians in a brusque and demanding way. Lewis nearly used violence to salve his frustrations and get the results he desired. ${ }^{27}$

Despite the near conflict, the explorers collected an impressive range of plants during the eleven days they spent traversing the Cascades and Celilo Falls region of the Columbia. Among the twenty new species they collected there, bare-stemmed desert-parsley (Lomatium nudicaule), thimbleberry (Rubus parviflorus), wild hyacinth (Brodiaea douglasii), rice root (Fritillaria lanceolata), golden currant (Ribes aureum), and fennel or yampah (Perideridia gairdneri) documented most directly the importance of gathered plants in the Indians' diet. At "Fort Rock" camp near The Dalles, the exploration party spent three days bargaining for horses with "Chilluckkitequaws" (Wishram-Wasco) before leaving the Columbia and traveling east on the northern shore of the river. They had camped in the same place on October 25-28, 1805, during their descent of the Columbia. Near present-day Mill Creek on the west end of The Dalles, the camp appealed to Clark, as he noted "a high point of rocks, which forms a kind of foritifcation in the Point between the river \& Creek ... we Conceive well Calculated for defence." It became their home from April 15 to April 18, and the time afforded them opportunity to collect several new species, some that Indians gathered as foodstuffs. ${ }^{28}$

On April 15, their first day at Fort Rock camp, the explorers collected desert-parsley, an important plant that Indians favored in the early spring 
for its sharp celery-like flavor and crispness. Indians ate the plant direct from the picking, but they also mashed and boiled it to make a strong soup that was rich in vitamin $C$. Lewis also collected a specimen of thimbleberry, a species closely related to salmonberry (Rufus vitifolius), which predominated on the lower river. He carefully distinguished between the two plants, noting that Indians ate the sprouts from the thimbleberry "without kooking." Two days later, while Clark traveled upriver in search of horses, hoping to strike a bargain with Tenino Indians near the Deschutes River, Lewis remained at the rock fort and continued surveying the area. He recorded Indian activities, fish resources, and his own plant collecting. During their time along Mill Creek, Lewis entered seven new plants into his growing catalog, but he took special note of Indian subsistence. "The inhabitants of the rapids, at this time [spring]," Lewis wrote, "take a few of the white salmon trout and considerable quantities of a small indifferent mullet on which they principally subsist." By white salmon Lewis and Clark generally meant coho or silver salmon (Oncorhynchus kisutch), which they first identified at The Dalles in October 1805; but coho migrate upstream from July to early autumn, so it is likely Lewis saw the earliest of the spring chinook (Oncorhynchus tshawytscha). The so-called mullet, on the other hand, was most likely the northern pikeminnow (Ptychocheilus oregonensis), a species of fish new to science. These fish scavenge a broad range of food and gather in significant numbers, which made them easy to capture. Because the Indians had little dried salmon left from the previous year, Lewis explained in his notes that "they subsist on roots principally with some dryed and pounded fish." The roots were important, as Clark made clear in his entry on the same day, commenting that women along the Columbia upriver from the Long Narrows were busy gathering roots. Among the important plants they gathered, wild hyacinth was a staple and valued for its vitamin-rich bulb. Indians gathered bushels of them in the spring to make several foods for immediate consumption. Lewis reported that they boiled them, baked them, or dried them in the sun. ${ }^{29}$

Lewis and Clark had been astonished by the number of fish they saw in the Columbia, and their journals include several descriptions of salmon and drawings of other fish they encountered. Nonetheless, they increasingly became aware of the reliance of Columbia River Indians on plant foods. Lewis recorded fennel, or yampah, on three occasions in the Columbia Basin, noting the Indian name as "year-pah." He commented on the anise flavor and the plant's favored place among Indian foods. He also collected rice root, another staple among mid-Columbia Indians. Lewis 


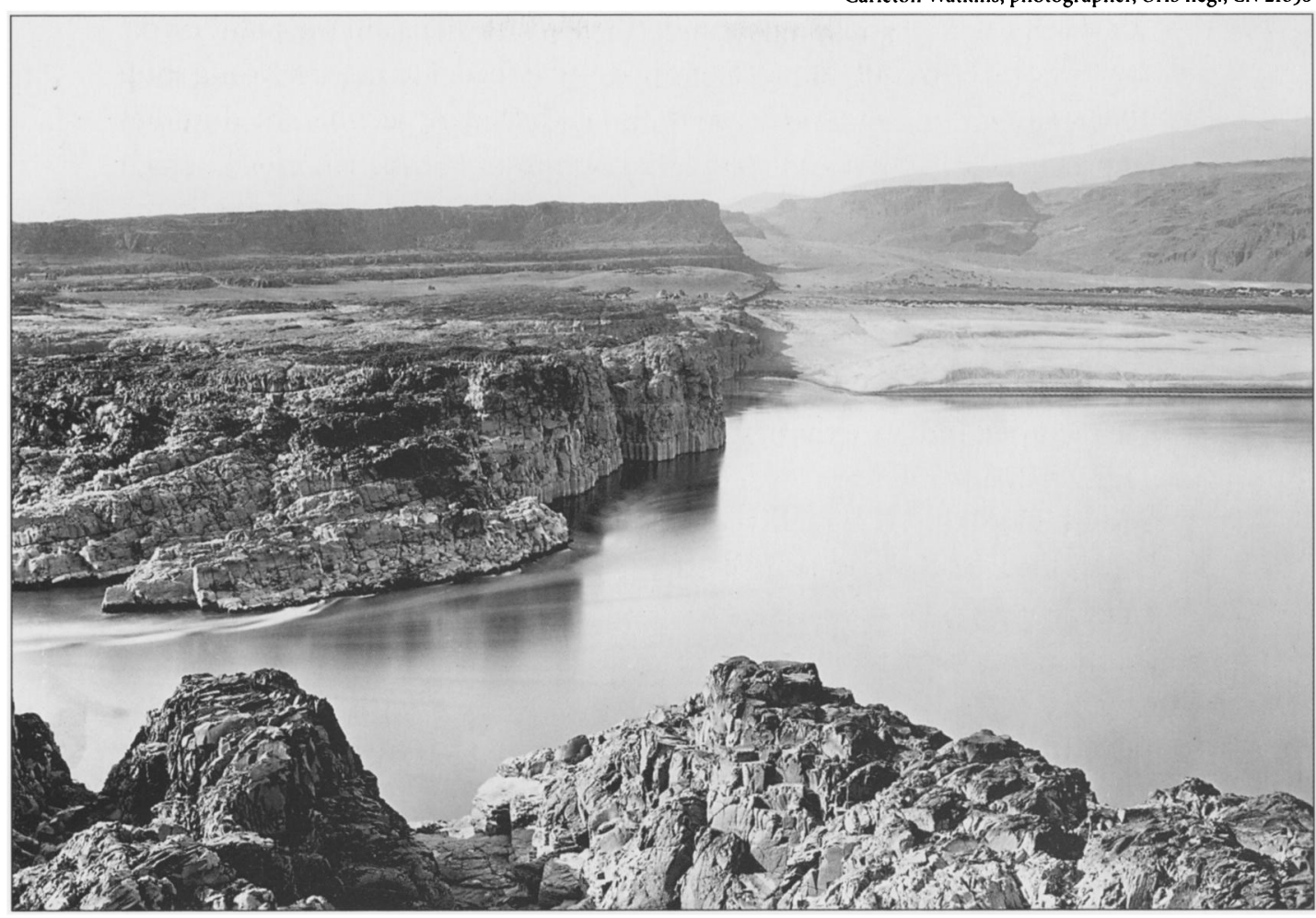

The landscape at The Dalles when Carleton Watkins took this photograph in 1882 had not changed appreciably since Lewis and Clark passed here in October 1805 and April 1806.

recorded the Indian name for the plant - "tel-lak-thil-pah" — and noted that Natives cooked the mashed plant bulb and ate it warm or cold. ${ }^{30}$

On April 20, the Corps of Discovery proceeded east from the Great Falls of the Columbia, perhaps grudgingly respectful of Indians' proprietary views about the land. They had learned a great deal about the river, the basalt geology, the limited resources, and the ways Indian people drew from their environment season by season. They recorded the villagers' economy with an eye for wealth in manufactured and natural goods. "The Enesher and Skillutes [near Celilo Falls] are much better clad than they were last fall," Lewis recorded in his journal. “... a considerable proportion of their wearing apparel is purchased from their neighbours to the N.W. in exchange for pounded fish copper and beads." Their houses impressed Lewis by their size and construction, and he commented on their economy and implements: "For fuel they use straw, small willows and the southern wood [sagebrush]. They use silk grass in manufacturing their fishing 
nets and bags, the bear grass and cedar bark are employed in forming a variety of articles." In short, Columbia River Indians' lives reflected their environment in dynamic ways, from house construction to fishing gear and fuel, and Lewis could see it all in one snapshot. Still, his frustrations with Indian behavior prompted him to add a discouraging reflection on the people of the falls: "they are poor, dirty, proud, haughty, inhospitable, parsimonious and faithless in every rispect.... These people have yet a large quantity of dryed fish on hand yet they will not let us have any but for an exorbitant price. we purchased two dogs." ${ }^{31}$

\section{Fort Clatsop at the Pacific Ocean}

By the time Lewis and Clark reached the Pacific Ocean, they had endured weeks of inclement weather, dangerous conditions on the river, and a general weakening of their condition. They debated whether staying at the coast or removing themselves upriver for the winter would best further their objectives. After discussion and polling the Corps, the captains followed what was likely their original preference - to stay at the coast and hope for contact with visiting mariners. From early December 1805 until near the end of the month, the men labored steadily building Fort Clatsop, a sturdy, twenty-five-hundred-square-foot pallisaded enclosure of seven buildings. Although Chinook and Clatsop Indians at the mouth of the river generally treated Lewis and Clark with generosity, the explorers formed negative opinions about them that mirrored their derogatory characterizations of the lower Columbia River environment. The weather made travel and living uncomfortable, while their exchanges with Indians made the explorers chary. Indians came to Fort Clatsop for trade, but the explorers' depleted trade-good inventory offered little the Chinooks or Clatsops did not already have from decades of trading with visiting mariners. The paucity of trade and the Indians' experience in trading with whites led to stiff bargaining and to Lewis's famous characterization of the Indians as "great higlers in trade." Nonetheless, the captains could well see that these people had mastered a difficult environment. They marveled at the Indians' great cedar canoes and at how easily they maneuvered them in the tempestuous Columbia River estuary. ${ }^{32}$

Fort Clatsop was home for the expedition force from December 1805 to March 1806. Unlike at Fort Mandan, where interaction with local Indians dominated daily life, the winter at Fort Clatsop was insular, with sentinels posted to approve entrance by Indians. Holed up nearly as prisoners of 


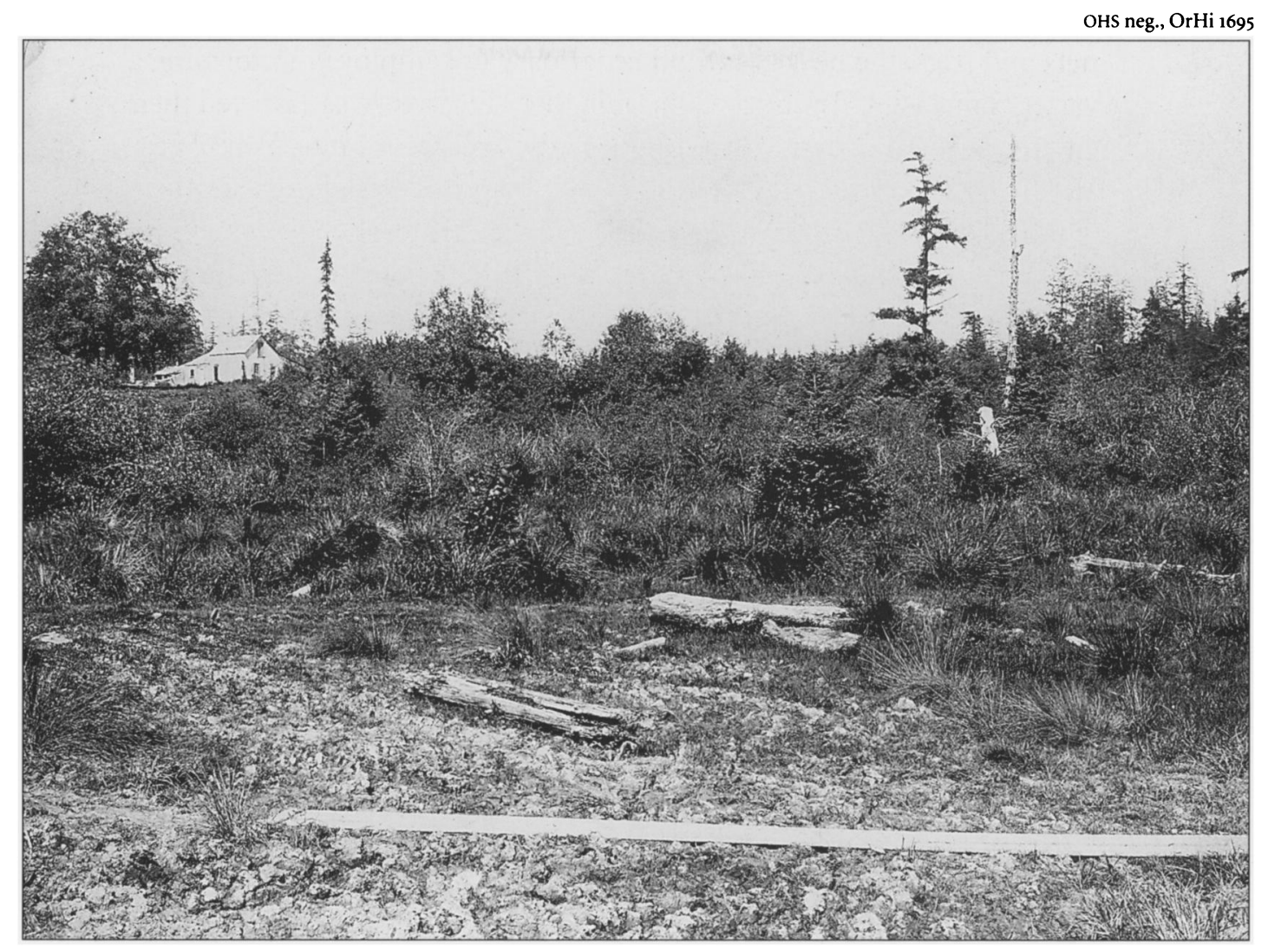

The site of Fort Clatsop, seen here in 1899, served as winter quarters for the Corps of Discovery in 1805-1806. On December 5, 1805, Lewis described the site as "a Situation on a Small river which falls into a Small bay."

the climate and their limited relations with Indians, the Corps kept busy at a range of tasks. They collected extensively, pursuing their scientific mission. By March, they had discovered thirty new animals and half that number of new plants and had described them for science, while they enumerated dozens of species they had already encountered. The journals at Fort Clatsop are filled with precise descriptions, measurements, and details about species' distribution, habitat, and unusual characteristics, plus sketches and drawings of important species on the lower Columbia. In part, this reflects Lewis's return to his journal writing on January 1, 1806, ending a period of silence in the journals since September 22, 1805. His writing at Fort Clatsop included a substantial collation of information the Corps had acquired over the preceding months in a section titled "Fort Clatsop Miscellany." In the "Miscellany," Lewis listed an estimate 


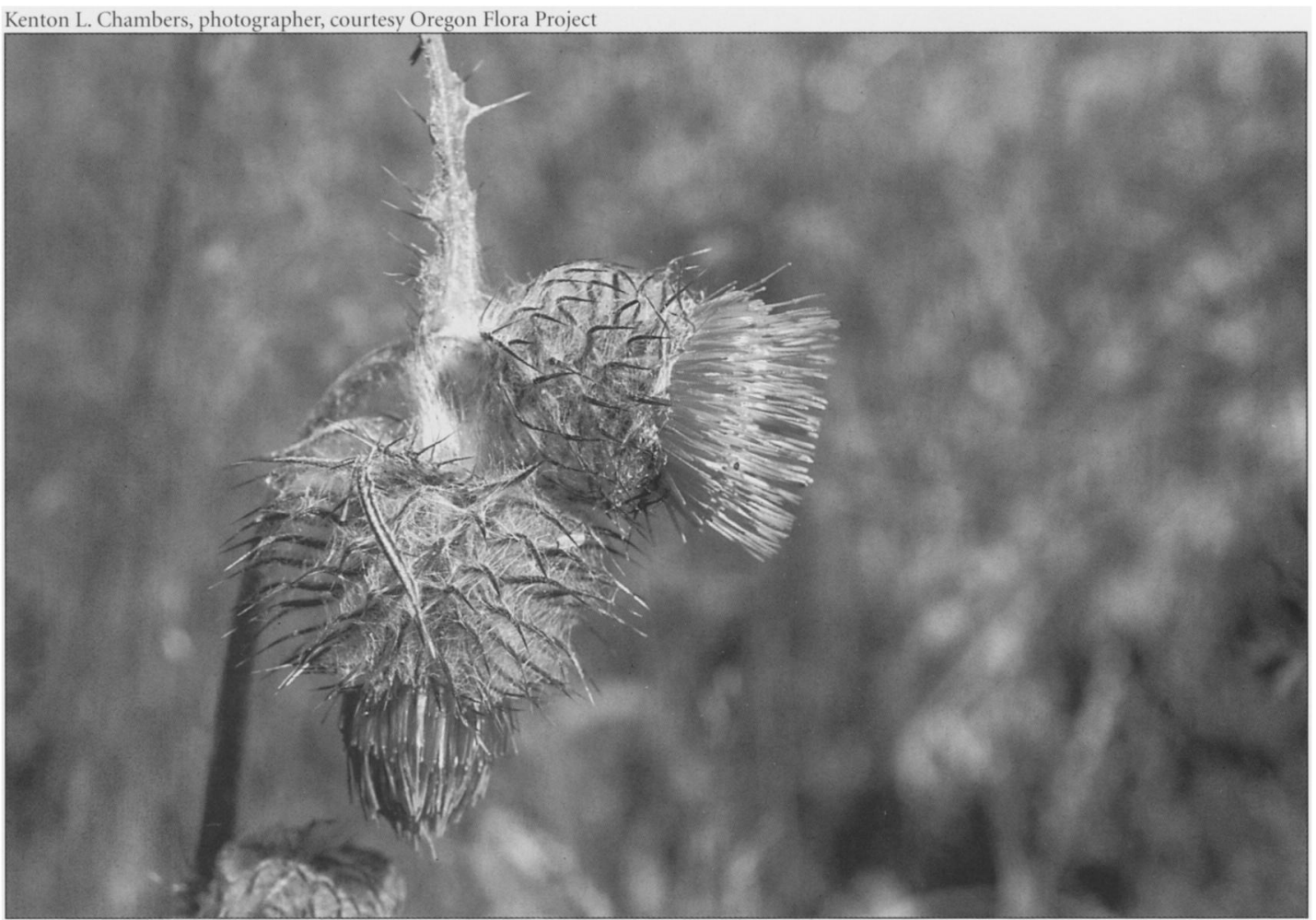

Lewis described the edible thistle, Cirsium edule, on January 21, 1806, at Fort Clatsop. The Clatsops called it Chan-ne-tak-que, he wrote, and ate it raw like a carrot or cooked it into a sugary pulp, much like camas root.

of distances traveled from Fort Mandan, place-names the Corps had given locations along the route, and a survey of Indian populations and their principal villages. Clark poured over his notes and field sketches and drew annotated route maps, some in extraordinary detail. While the captains added documentation to the expedition, the men worked assiduously at repairing clothing and making moccasins from elk and deer hides, when they were not searching for elusive elk and deer in the dense rainforest. ${ }^{33}$

Indian use of plants on the lower Columbia fascinated Lewis and Clark. They could not miss the importance that cedar, fir, spruce, and pine played in Indian material culture. At Fort Clatsop, they recorded the first descriptions of grand fir (Abies grandis), Oregon ash (Fraxinus latifolia), Sitka spruce (Picea sitchensis), and mountain hemlock (Tsuga mertensiana). They took special note of the Indians' use of the inner bark from western red cedar, which was stripped and plaited to craft watertight baskets and 
hats and various articles of clothing. ${ }^{34}$ Indians used conifer fibers, logs, and cones from several species for canoes, houses, construction materials, tools, and more. Cedar provided the straight-grained timbers for canoes, and Indians used Sitka spruce for their plank houses. Lewis also recorded the Clatsops' use of crabapple wood (Pyrus fusca) - an addition to his scientific catalog - on January 28 :

The wood of this tree is excessively hard when seasoned. the natives make great uce of it to form their wedges with which they split their boards of pine for the purpose of building houses. these wedges they also employ in splitting their fire-wood and in hollowing out their canoes. I have seen the natives drive the wedg of this wood into solid dry pine which it cleft without fracturing or injuring the wedge in the smallest degree. ${ }^{35}$

Lewis added that the explorers saw the same utility and used the wood "for ax handles as well as glutts or wedges," an example of the Corps learning about natural resources by watching and imitating Indian technologies. The explorers probably used Sitka spruce to construct Fort Clatsop, noting that it was the preferred construction wood among the Clatsops and, as Lewis commented, it "rives better than any species we have tried." ${ }^{36}$

The Corps relied on Indians in other ways at Fort Clatsop. The region did not provide easy access to the red meat they preferred, so they consumed more plant foods than they probably desired. There were plenty of fish, but the Corps left the lower river before the massive spring chinook salmon migrations, and in any case they had no love of fish and had consistently chosen dogs over fish on their descent of the river. Indians traded dried fish, wapato, and a variety of plants for the few articles Lewis and Clark could afford to offer. Wapato did not grow in the Columbia estuary, but it was a favored food and practically a staple plant food on the lower river that Chinook and Clatsop traders acquired from tribes farther up the Columbia. There were many local plants, however, that Indians gathered and used during the winter as a complement to dried fish. On January 21, visiting Clatsops left the Corps with a species new to Lewis, an edible thistle (Cirsium edule) that grew to six feet and featured a bristly flowering purple head, a plant the Indians called "shan-ne-tah-que." Lewis reported that Indians used the plant's white and crisp root, which was "from 9 to 15 Inces in length and about the size of a mans thumb." It could be eaten like a carrot, but when prepared as a cooked mash, as Lewis described it, "it becomes black, and is more shugary than any fruit or root that I have met with in uce among the natives; the sweet is precisely that of the sugar in flavor." The thistle and berries from two new species that 


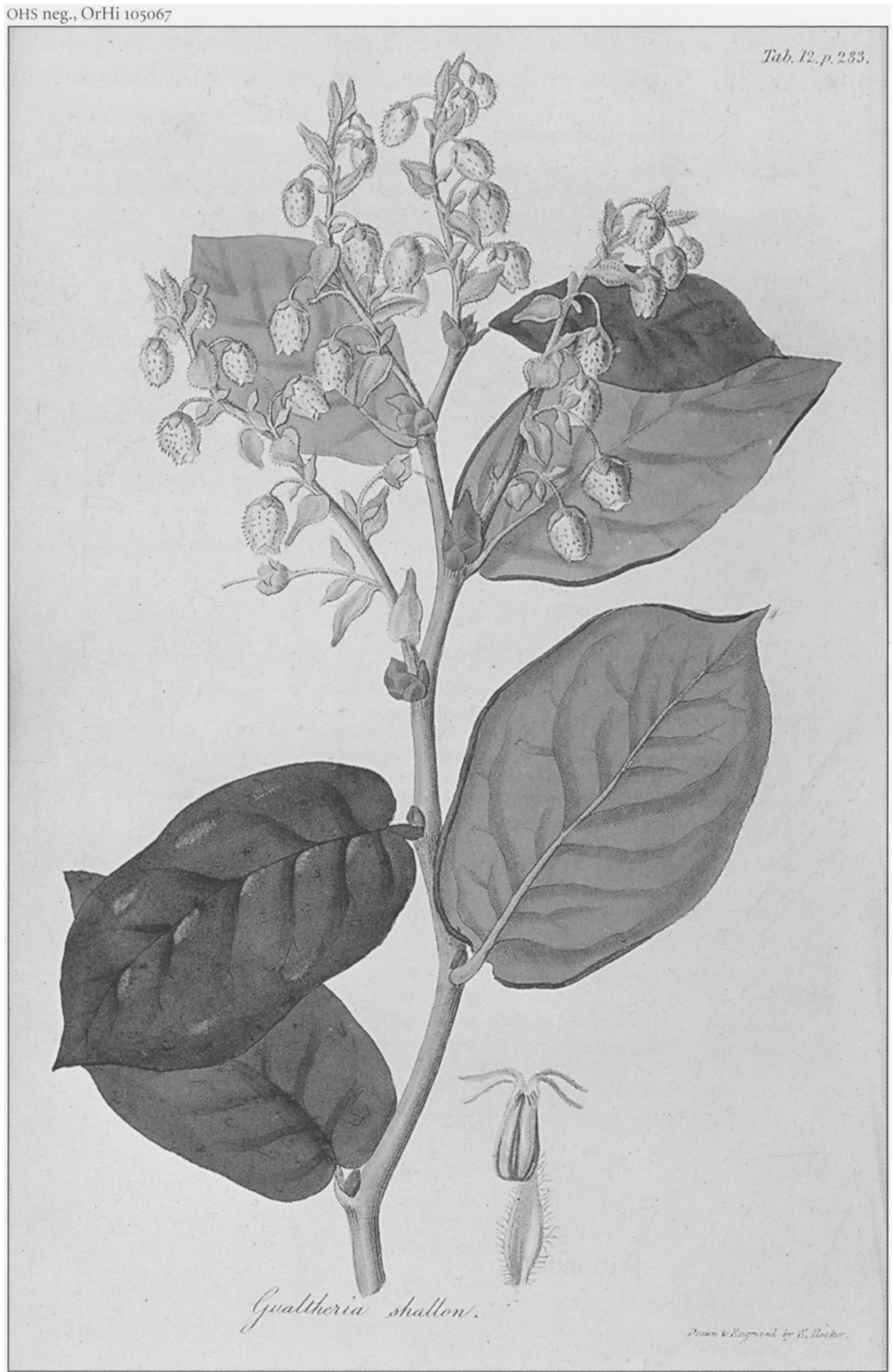

Lewis compared salal, Gaultheria shallon, to laurel and noted that it was a favorite browse for elk on the lower Columbia. He collected a specimen and Frederick Pursh included it in his Flora Americae Septentrionalis in 1814. 
Lewis described in his journal — salal (Gaultheria shallon) and evergreen huckleberry (Vaccinium ovatum) — were favorite sweet flavorings that the men mixed with dried elk meat. ${ }^{37}$

Although they did not prefer fish as food, Lewis and Clark identified several fish new to science during their stay at the mouth of the Columbia, and their descriptions included careful notations on when and how Indians took fish. They seemed only dimly aware of the staggered fish runs on the Columbia and of which fish predominated in what seasons. They first saw white sturgeon (Acipenser transmontanus), for example, in November when Chinook Indians offered it for food as the Corps beat its way toward the ocean. In early December, Clark noted sturgeon again when he visited a Chinook village, where they "depended in Some Measure for their winters Subsistence on the fish which is thrown on Shore and left by the tide." Clark also commented on the same phenomenon in January, when he discovered Tillamook Indians taking sturgeon on the shore, "when the Salmon was Scerce." In precise detail, Lewis described Indians cooking sturgeon by filleting them and steaming them in alternating layers with salal or other boughs. In addition, the Indians rendered sturgeon to make strong glue, which they used to fabricate exceptionally powerful and flexible bows made of cedar and elk sinew. As they had at The Dalles, the explorers began to recognize the integral and important ties between the environment and the people who lived in it..$^{38}$

In late February, Indians introduced Lewis and Clark to another species of fish new to science, the eulachon (Thaleichthys pacificus). Clatsop Chief Coboway came to the fort with a dozen men, women, and children to engage in trade. Part of his offering was a basket of eulachon, or candlefish, which are rich in oil and run by the millions in the lower Columbia in the late winter. The fish, Lewis recorded, "are taken in great quantities in the Columbia R. about 40 miles above us by means of skiming or scooping nets." Eulachon are anadromous fish that teem in tributary streams - the Cowlitz, Lewis, Willamette, and Sandy — in the lower Columbia. They are easily netted, as they spawn by the thousands at night. The fish could be eaten with little preparation and were "so fat," Lewis noted, that "they require no additional sauce, and I think them superior to any fish I ever tasted.... the bones are so soft that they form no obstruction in eating this fish." In great detail, Lewis described the fish - its eyes, fins, scale structure, abdomen, jaws - and concluded that it was an anchovy "of the Malacopterygious Order \& Class Clupea," one of the few times he used Linnaean typology to label species. By early March, they had become 
devotees of the small fish, exclaiming about their delicacy and good taste. "The natives run a small stick through their gills," Lewis explained in his entry for March 4, 1806, "and hang them in the smoke of their lodges, or kindle a small fire under them for the purpose of drying them." ${ }_{39}$

Lewis and Clark spent just over three months at Fort Clatsop. While they waited hopefully for a trading ship, they surveyed the region, significantly increasing their catalog of new species. Their relations with the Chinooks and Clatsops included beneficial exchanges and genuine harmony, but on the whole the relationships were cool and eventually broke down. Eager to leave the damp and confining environment of their winter quarters to return east, the Corps schemed in early March to acquire canoes for their upriver journey. They failed to strike a bargain with the Clatsops and resorted to stealing a substantial and valuable canoe for the eastward voyage. Lewis and Clark had learned a great deal during their winter on the coast, especially about the area's rich environment, the relative wealth of the tribes in the region, and the strategic economic potential of the lower Columbia River. Yet, their patience grown thin, they ignored the Indians' advice that travel over the mountains would have to wait until late spring. On March 23, 1806, Lewis handed over Fort Clatsop to Coboway, and the Corps headed upriver. ${ }^{40}$

\section{Camp Chopunnish on the Vlearwater}

When the Corps reached the familiar landscape of the Clearwater River of present-day Idaho and the Nez Perce camps in mid-May, snow still lay deep in the high country, blocking the mountain passes in the Bitterroots. By leaving too soon from Fort Clatsop, the Corps avoided fighting the stronger current that accompanied the spring freshet, when melting snow swelled the Columbia and brought its great volume rushing through the Gorge, but they also missed the first of the salmon runs at The Dalles, which would have provided them with fresh fish and perhaps improved their relationships with Indians who would have been engaged in fishing. Leaving too soon also meant a long stay in the Nez Perce camps where, as Lewis put it, they cursed "that icy barrier which separates me from my friends and Country, from all which makes life esteemable." They spent nearly a month at Camp Chopunnish, where they had to rely on Indian generosity for support. Their stock of trade items had dwindled to a few trinkets that were of little interest to the Nez Perces, forcing the Corps to cannibalize their own clothing, equipment, and tools for tradable metal 

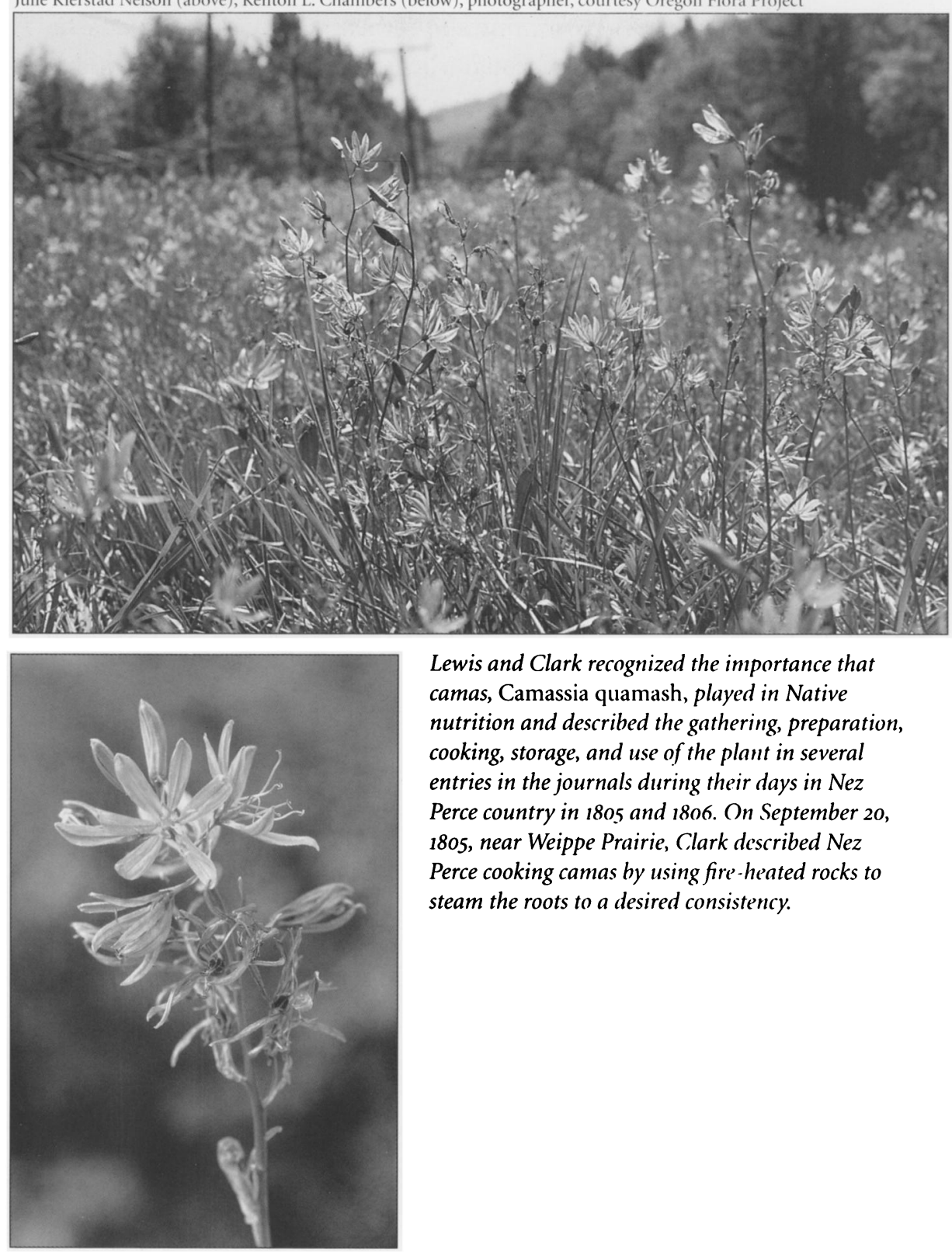

Lewis and Clark recognized the importance that camas, Camassia quamash, played in Native nutrition and described the gathering, preparation, cooking, storage, and use of the plant in several entries in the journals during their days in Nez Perce country in 1805 and 1806. On September 20, 1805, near Weippe Prairie, Clark described Nez Perce cooking camas by using fire-heated rocks to steam the roots to a desired consistency.

items. Clark reciprocated the Indians' generosity by ministering to tribal members who needed medical care. ${ }^{41}$

Reaching the Nez Perce camps in early May, Lewis and Clark quickly discovered that a row among Nez Perce chiefs had resulted in the dispersal of horses they had left in the Indians' care the previous year. After a day or 
two of discussions between the captains and the Nez Perce chiefs, the horses were rounded up and the Corps established a camp along the Clearwater River. They planned to refit, get the Nez Perces to furnish guides for the Bitterroot crossing, as they had for the descent of the Columbia the year before, and make their way over the mountains at the earliest moment. By early June, snow still blanketed the pass, but the captains determined to try a crossing, even though the Nez Perces warned against it and refused to provide a guide. "The [Clearwater] river has been falling for several days," Lewis wrote on June 9, "and is now lower by near six feet than it has been; this we view as a strong evidence that the great body of snow has left the mountains." He was wrong, and the foray into the mountains turned to near disaster when the party faced twelve-foot snowdrifts, forcing them to turn back. Finally, on June 25, 1806, after they had coaxed two Nez Perce to guide them, the Corps made their way east on the Lolo Trail..$^{42}$

Their forced stay on the Clearwater River offered the explorers more opportunity to enlarge their scientific catalog. While the Corps waited out the spring in the Nez Perce camps, Lewis collected nearly a quarter of the total number of specimens in his herbarium and described nearly onethird of all the new species he discovered during the expedition. Among his finds were important root foods the Nez Perces relied on - small camas (Camassia quamash), cous biscuitroot (Lomatium cous), elegant mariposa lily (Calochortus elegans), and yellow bell or yellow fritillary (Fritillaria pudica). Lewis and Clark had recognized the importance of root plant foods in 1805 when they staggered hungrily out of the Bitterroot Mountains and eagerly ate roots provided by the Nez Perces, which gave them nourishment but made them ill. In 1806, they took more notice of the plants that sustained the Indians through the long winters, although they initially refused an offer on May 10 of two bushels of camas and four cakes made of cous and dried fish, no doubt remembering their earlier experience. $^{43}$

Camas and cous were among the most important plant foods on the Columbia Plateau. Camas grows in wet and even flood-prone mountain meadows enclosed by fir or pine forests that are rich in alluvial soils. Flowering between April and July, depending on elevation, the numerous fields of the rich, edible bulb provided nearly four months of harvest, which took Nez Perce women to meadows and hillsides across the valleys and benchlands in the Clearwater and Snake river drainages. Important camas harvest grounds appear on a map of the river courses and mountain formations between the Missouri and Columbia rivers that Clark drew 
from Native information, an indication of how important the camas grounds were and how the Nez Perces oriented the significant places in their physical world. ${ }^{44}$

Lewis and Clark had seen camas at several locations in the Columbia River Basin and noticed that the plants in the middle elevations grew abundantly and seemingly played a large role in Indian subsistence. In early June, after their abortive first attempt to travel on the Lolo Trail, the Corps determined "to remove from hence to the quawmash grounds" at Weippe Prairie, a two-thousand-acre meadow that with the blue camas in bloom looked to Lewis like a "lake of fine clear water." During their extended stay, Lewis wrote one of the longest and most detailed descriptions of a plant to be found in the journals. "As I have had frequent occasion to mention the plant which the Chopunnish [Nez Perce] call quawmash I shall here give more particular description of that plant ... [which] forms much the greatest portion of their subsistence." He described camas as a waterloving plant that "you will seldom find ... more than a few feet from the inundated soil." Its bulb, the edible portion of the plant, he found "almost tasteless and without smell in its unprepared state," but once cooked in a several-step process, the bulbs "are soft of a sweetish tast and much the consistency of a roasted onion." Although Lewis considered the food "palatable," he added that it "disagrees with me in every shape I have ever used it." Even so, his careful scientific description connected Nez Perce women - from the harvest of camas to its preparation as eaten and stored food - with an environment he saw in full bloom. ${ }^{45}$

Unlike camas, the cous or bisquit-root plant grows on dry slopes, often in rocky terrain in medium to high elevations. Cous is harvested at about the same time as camas, but the harvesting areas are more limited and smaller in scope. Indians throughout the Columbia Plateau made a versatile bread out of a mash that had been pounded in a pestle by Indian women. "[T]he noise of their women pounding roots," Lewis wrote on May 10, 1806, at a Nez Perce camp on Lawyer Creek, "reminds me of a nail factory." Women collected cous "as early as the snows disappear in the spring and continue to collect it until the quawmash supplys its place which happens about the latter end of June." In addition to bread, cous made a "thick muselage," which Lewis called "much the most agreeable ... [with] the flavor ... not very unlike the gensang." The porridge Lewis described is mentioned in his journal entry for May 12 as a staple at a Nez Perce council, which began with servings of cous and ended with a "loud and animated harangue of the Chief." ${ }^{46}$ 
Lewis understood the importance of adequate and reliable foods to the Nez Perces and other Indians in the Columbia River Basin. He knew how central plants and animals were to Indians' diets, but he also discovered that the labor of gathering, preparing, preserving, and serving those foods ran directly through the heart of Indian life, that it was central to understanding their lives in the Columbia Basin environment. ${ }^{47}$ It is clear from the journals that the explorers, especially Lewis, increasingly saw many of the plants and animals they described for science through the lens of culture. A good deal of that learning took place in the Columbia River Basin, where they added so many species to the scientific catalog.

Jefferson's instructions had rested on principles of Enlightenment science and inquiry that challenged the explorers to fill in the frame of nature by bringing back a broad and complete portrait of the territory beyond the charted regions of the West. The president's interest in Indians in the West - the "names of the nations \& their numbers" - became questions in his instructions about economics, politics, morality, disease, and language, but inherent in those instructions was the grander ideal and larger ambition of describing an uncataloged environment and how it sustained people..$^{8}$ Lewis and Clark returned with journals filled with observations, notations, and scientific descriptions to those ends. Their records are mostly undigested, often graphically direct, and largely bereft of interpretation or personal affectation. Their descriptions of this region, however, remind us that understanding our world through science should be holistic and inclusive of nature and culture. The nearly one million words the captains and their men recorded offer us a thinly glazed window on the Columbia River Basin of two centuries ago and invite us to compare that environment with the one we know today.

\section{Notes}

1. William Clark, Fort Clatsop Miscellany, Estimated Distances, in The Journals of the Lewis and Clark Expedition, ed. Gary E. Moulton (Lincoln: University of Nebraska Press, 1983-2001), 6:451.

2. Meriwether Lewis, August 12, 1805; Lewis, August 13, 1805; Clark, August 23, 1805, in Moulton, ed., Journals, 5:74, 81, 156. On Lewis and Clark's adherence to theories of North American geography, see John Logan Allen, Passage through the Garden: Lewis and Clark and the Image of the Pacific Northwest
(Urbana: University of Illinois Press, 1975), 18-19, 283-90, 291n18.

3. Francis Biddle, History of the Expedition Under the Command of Captains Lewis and Clark, 2 vols. (Philadelphia: Paul Allen, 1814); and Stephen E. Ambrose, Undaunted Courage: Meriwether Lewis, Thomas Jefferson, and the Opening of the American West (New York: Simon \& Schuster, 1996). Frederick Pursh published Flora Americae Septentrionalis, which included a sizable part of the herbarium collected by Lewis and Clark 
during the expedition, in London in 1814 , the same year Biddle published. Although both were among the first publications directly from the expedition, the scientific information in Pursh's Flora cast a much narrower and shorter shadow than Biddle's History.

4. Donald Worster, Nature's Economy: A History of Ecological Ideas, $2^{\mathrm{d}} \mathrm{ed}$. (New York: Cambridge University Press, 1994), 36-56. See also Peter J. Bowler, The Norton History of the Environmental Sciences (New York: W.W. Norton, 1992), 139-54.

5. Thomas Jefferson to George Rogers Clark, December 4, 1783; George Rogers Clark to Jefferson, February 8, 1784, in Donald Jackson, ed. Letters of the Lewis and Clark Expedition, 2 vols., $2^{\mathrm{d}} \mathrm{ed}$. (Urbana: University of Illinois Press, 1978) 2:654-5, 656.

6. John Ledyard to Jefferson, November 25, 1786; Jefferson to Andre Michaux, April 30, 1793, in Jackson, ed., Letters, 2:669-72. On the Michaux connection, see James P. Ronda, "Dreams and Discoveries: Exploring the American West, 1760-1815," William and Mary Quarterly, $3^{\mathrm{d}}$ ser., 46 (January 1989):145-62; Douglas L. Wilson, “Thomas Jefferson's Library and the French Connection," Eighteenth Century Studies 26 (Summer 1993):669-85. On Michax and American botanical studies, see John C. Greene, American Science in the Age of Jefferson (Ames: Iowa State University Press, 1984), 109, 263-4. On Ledyard's plan and writing, see Larzer Ziff, Return Passages: Great American Travel Writing, 1780-1910 (New Haven, Conn.: Yale University Press, 2000), 1-6, 17-57; and Laurie Winn Carlson, Seduced by the West: Jefferson's America and the Lure of the Land beyond the Mississippi (Chicago: Ivan R. Dee, 2003), 25-40. By an odd coincidence, both Ledyard and Michaux died in Africa as a consequence of scientific explorations, Ledyard in 1789 and Michaux in 1802 .

7. Jefferson to Lewis, June 20,1803 , in Jackson, ed., Letters, 1:61-6. Representatives in each state received the questions, but only Jefferson and Gov. John Sullivan of New Hampshire responded to the queries. Jefferson drafted Notes in 1782, but it was not published until 1787 in London. See Charles A. Miller, Jefferson and Nature: An Interpretation (Baltimore, Md.: Johns Hopkins University Press, 1988), 16-20; Greene, American Science,
197-8; Paul Russell Cutright, Lewis and Clark: Pioneering Naturalists (Urbana: University of Illinois Press, 1969), 1-29; Silvio A. Bendini, "The Scientific Instruments of the Lewis and Clark Expedition," in James P. Ronda, ed., Voyages of Discovery: Essays on the Lewis and Clark Expedition (Helena: Montana Historical Society Press, 1998), 143-68; and William F. Willingham and Leonoor Swets Ingraham, eds, Enlightenment Science in the Pacific Northwest: The Lewis and Clark Expedition (Portland, Ore.: Lewis and Clark College, 1984).

8. Jefferson to E.I. du Pont de Nemours, March 2, 1809, in Brooke Hindle, The Pursuit of Science in Revolutionary America, 1735-1789 (Chapel Hill: University of North Carolina Press, 1956), 319.

9. Miller, Jefferson and Nature, 219. See also William Bartram, Travels through North and South Carolina ... (Philadelphia: James \& Johnson, 1791); John Filson, The Discovery, Settlement, and Present State of Kentucke (Wilmington, Del.: James Adams, 1784); David Ramsay, The History of South Carolina, 2 vols. (n.p.: David Longworth for the author, 1809); and Samuel Williams, The Natural and Civil History of Vermont (Walpole, N.H.: printed by Isaiah Thomas and David Carlisle, 1794). On the American Philosophical Society and science, see Hindle, Pursuit of Science, 127-45; William E. Lingelbach, "The Library of the American Philosophical Society," William and Mary Quarterly, $3^{\mathrm{d}}$ ser., 3 (January 1946): 56-7; and John C. Greene, "American Science Comes of Age," Journal of American History 55 (June 1968): 22-48.

10. Thomas Jefferson, Notes on the State of Virginia, ed. William Peden (New York: W.W. Norton, 1954), 54.

11. Philip Sloan, "The Gaze of Natural History," in Christopher Fox, Roy Porter, and Robert Wokler, eds., Inventing Human Science: Eighteenth-Century Domains (Berkeley: University of California Press, 1995), 112-51; Herbert Leventhal, In the Shadow of the Enlightenment: Occultism and Renaissance Science in Eighteenth-Century America (New York: New York University Press, 1976), 233-6, 259; Miller, Jefferson and Nature, 32-4; Thomas Jefferson, Notes on the State of Virginia, in Thomas Jefferson: Writings (New York: Library of America, 1984), 176-7. 
In an important way, Jefferson's pursuit of natural history allied him with Linnaeus in his general adherence to the Great Chain of Being viewpoint on describing nature, while his hope that Lewis and Clark would discover evidence of Buffon's mistaken characterization of the Americas put him at odds with the Linnaean description of a world without zoogeographical distinctions. For discussions of Linnaeus and Humboldt, see Worster, Nature's Economy, 131-43, 156; and Bowler, Norton History of Environmental Sciences, $170-84$.

12. Albert Furtwangler, Acts of Discovery: Visions of America in the Lewis and Clark Journals (Urbana: University of Illinois Press, 1993), 86.

13. Nigel Leask, Curiosity and the Aesthetics of Travel Writing, 1770-1840 (New York: Oxford University Press, 2002), 247-9; Charlotte M. Porter, The Eagle's Nest: Natural History and American Ideas, 1812-1842 (Tuscaloosa: University of Alabama Press, 1986), 15-17, 29; Thomas Slaughter, Exploring Lewis and Clark: Reflections on Men and Wilderness (New York: Alfred A. Knopf, 2003), 3-47. See also Barbara Belyea, "Heroes and Hero Worship: Alexander Mackenzie's Influence on the Lewis and Clark Expedition Journals," Oregon Humanities (Spring 2004): 38-43.

14. Jefferson, Notes on Virginia, ed. Peden, 62, Pamela Regis, Describing Early America: Bartram, Jefferson, Crevecour, and the Rhetoric of Natural History (DeKalb: Northern Illinois University Press, 1992), 100-104; Larzer Ziff, Writing in the New Nation: Prose, Print, and Politics in the Early United States (New Haven, Conn.: Yale University Press, 1991), 151-4; Greene, American Science, 376-83.

15. James P. Ronda, Lewis and Clark among the Indians (Lincoln: University of Nebraska Press, 1984), 113-22, 181-213.

16. Elijah Harry Criswell, "Lewis and Clark: Linguistic Pioneers," University of Missouri Studies 15 (April 1940); Cutright, Pioneering Naturalists, 259. Cutright lists 122 species of animals new to science described by Lewis and Clark, 65 of them discovered in the Columbia River Basin, and 178 plants new to science, 140 of them found in the Columbia River Basin (pp. 423, 447).

17. Clark, October 22, 1805, in Moulton, ed., Journals, 5:320. The village site described in this passage is approximately at the present-day site of Wishram, Washington, upstream from Celilo Falls.

18. Ronda, Lewis and Clark among the Indians, 170-4; Gary E. Moulton, ed. Atlas of the Lewis and Clark Expedition, vol. 1 of Moulton, ed., Journals (Lincoln: University of Nebraska Press, 1983), maps 77 and 78; and sketch maps, from Elkskin-bound Journal and Codex H, p. 1, in Moulton, ed., Journals, 5:316, 322.

19. Clark, October 21, 1805, in Moulton, ed., Journals, 5:318.

20. Clark, November 1, 1805, in Moulton, ed., Journals, 5:373. See also William L. Lang, "Lewis and Clark on the Columbia River: The Power of Landscape in the Exploration Experience," Pacific Northwest Quarterly 87 (Summer 1996): 141-8.

21. Clark, October 22, 1805, in Moulton, ed., Journals, 5:325.

22. Clark, October 24, 25, 1805, in Moulton, ed., Journals, 5:333, 339.

23. Gary E. Moulton, ed. Herbarium of the Lewis and Clark Expedition, vol. 12 of Moulton, ed., Journals (Lincoln: University of Nebraska Press, 1999), plate 1a; Cutright, Pioneering Naturalists, 239, 400; H. Wayne Phillips, Plants of the Lewis and Clark Expedition (Missoula, Mont.: Mountain Press, 2003), 250; Eugene S. Hunn, Nch'i-Wána, "The Big River": Mid-Columbia Indians and Their Land (Seattle: University of Washington Press, 1990), 119. See also Paul Russell Cutright, "Meriwether Lewis: Botanist," Oregon Historical Quarterly 69 (June 1968): 148-70.

24. Clark, February 12, 1806, in Moulton, ed., Journals, 6:300-301; Phillips, Plants of Lewis and Clark, 254.

25. Clark, October 21, 22, 1805, in Moulton, ed., Journals, 5:317, 323; Phillips, Plants of Lewis and Clark, 238; Moulton, ed., Herbarium, plate 146a; Cutright, Pioneering Naturalists, 229, 416. Lewis described and collected Oregon oak going upriver in March 1806 near present-day Clatskanie, Oregon.

26. Clark, October 29, 1805, in Moulton, ed., Journals, 5:349; Cutright, Pioneering Naturalists, 229. On the intersections of natural and human ecology on the Columbia, see Hunn, Nch'i-Wána, 89-137.

27. Lewis, April 22, 1806, in Moulton, ed., 
Journals, 7:156; Ronda, Lewis and Clark among the Indians, 220.

28. Clark, October 25, 1805; Lewis, April 15, 1806, in Moulton, ed., Journals, 5:339, 7:123, Cutright, Pioneering Naturalists, 289, 413; Hunn, Nch'i-Wána, 170-1.

29. Lewis, April 17, 1806; Clark, April 17, 1806, in Moulton, ed., Journals, 7:130-4; Cutright, Pioneering Naturalists, 426; Hunn, Nch'i-Wána, 172-5; Phillips, Plants of Lewis and Clark, 196; Moulton, ed., Herbarium, plates $154,171 \mathrm{~b}$. The notation on the specimen dates the collection as April 20, which suggests that Lewis may have written his journal entry for April 17 on April 20.

30. Lewis, April 15, 1806, Journals, 7:123-5; Moulton, ed., Herbarium, plates 6, 71a; Hunn, Nch'i-Wána, 172-3.

31. Lewis, April 20, 1806, in Moulton, ed., Journals, 7:145-6.

32. Ronda, Lewis and Clark among the Indians, 181-6.

33. Cutright, Pioneering Naturalists, 254-63; Moulton, ed., Journals, 6:156-8. See also Gary E. Moulton, "Meriwether Lewis's Missing Journals," Montana, The Magazine of Western History 35 (Spring 1985): 28-39.

34. Lewis, January 17, 19, 1806, in Moulton, ed., Journals, 6:214-15, 222.

35. Lewis, January 28, 1806, in Moulton, ed., Journals, 6:243; Cutright, Pioneering Naturalists, 248.

36. Lewis, January 28,1806 , in Moulton, ed., Journals, 6:243.

37. Lewis, January 21, 1806; Clark, February 7,1806 , in Moulton, ed., Journals, 6:226, 286; Phillips, Plants of Lewis and Clark, 230, 232; Cutright, Pioneering Naturalists, 264-6.

38. Clark, November 20, December 10, 1805, January 8, 1806; Lewis, March 4, 1806, in Moulton, ed., Journals, 6:72, 121, 184, 6:378.
39. Lewis, February 24, March 4, 1806, in Moulton, ed., Journals, 6:342-4, 378. On Coboway, see James P. Ronda, "Coboway's Tale," in Power and Place in the North American West, ed. Richard White and John Findlay (Seattle: University of Washington Press, 1999), 3-22.

40. Ronda, Lewis and Clark among the Indians, 213.

41. Lewis, May 17, 1806, in Moulton, ed., Journals, 7:267; Ronda, Lewis and Clark among the Indians, 229-31, Cutright, Pioneering Naturalists, 291-2; Allen, Passage through the Garden, 344-5; David J. Peck, Or Perish in the Attempt: Wilderness Medicine in the Lewis and Clark Expedition (Helena, Mont.: Farcountry Press, 2002), 240-54.

42. Lewis, June 9, 1806, in Moulton, ed., Journals, 7:349; Ronda, Lewis and Clark among the Indians, 226-7, Allen, Passage through the Garden, 346-7; Ambrose, Undaunted Courage, 359-65.

43. Clark, May 10, 1806, in Moulton, ed., Journals, 7:239. Clark prevailed on the Nez Perces to supply them with a horse, which they killed and ate with camas bread.

44. Moulton, ed., Atlas, map 98. See also Robert Carriker's article in this issue.

45. Lewis, June 3, 11, 12, 1806, in Moulton, ed., Journals, 7:331, 8:13-17, 22; Moulton, ed., Herbarium, plate 33; Cutright, Pioneering Naturalists, 300-1; Phillips, Plants of Lewis and Clark, 154.

46. Lewis, May 9, 10, 12, 1806, in Moulton, ed., Journals, 7: 234, 239, 246; Moulton, ed., Herbarium, plate 93; Cutright, Pioneering Naturalists, 283-4, 288; Phillips, Plants of Lewis and Clark, 212-13.

47. See Hunn, Nch'i-Wána, 110.

48. Jefferson to Lewis, June 20, 1803, in Jackson, ed., Letters, 1:62. 